\title{
Defining and measuring population health quality of outpatient diabetes care in Israel: lessons from the quality indicators in community health program
}

\author{
Leonard M. Pogach ${ }^{*}$ (ID and David C. Aron
}

\begin{abstract}
In Israel, as in other Organization for Economic Co-operation and Development countries, performance measurement is a key public health strategy in monitoring and improving population health outcomes. The Israeli Quality Indicators in Community Healthcare $(\mathrm{QICH})$ program has utilized electronic health records to monitor ambulatory care for the entire Israeli population since 2002. In 2006 the measures were updated to include laboratory values. They have been subsequently revised by stratifying by age, duration, adding medications, and changing frequency of testing for certain process measures. However, the $\mathrm{QICH}$ glycemic control measures do not address co-morbid conditions either thru exclusion criteria or higher target ranges. They also do not address potential over treatment in patients with complex medication conditions.

In the United States there have also been changes in nationally endorsed diabetes specific performance measures since 2007. However, there have also been public disagreements among United States professional societies, government agencies, and performance measurement organizations as to whether the current glycemic dichotomous ("all or none") threshold measures, without exclusion criteria, are consistent with the most recent evidence. Specifically, most guidelines now recommend individualized target goals based upon co-morbid conditions, risk of harms from medications, and patient preferences.

Concerns have been raised that the current glycemic performance measures have resulted in inappropriate care, such as medication over-treatment, and serious harms, such as hypoglycemia, especially in older adults. There currently are no national surveillance systems or measures that monitor these untoward outcomes.

We recommend several actions that QICH could consider to advance diabetes specific performance measurement science and population health: Convene an international conference; implement technical modifications of current measures and surveillance systems; and, most importantly, acknowledge patient autonomy by developing measures that document individualization of target values using shared decision making.
\end{abstract}

Keywords: Diabetes measures, Population health, Complex conditions, Unintended harms

* Correspondence: len.pogach@verizon.net

Livingston, USA

(C) The Author(s). 2018 Open Access This article is distributed under the terms of the Creative Commons Attribution 4.0 International License (http://creativecommons.org/licenses/by/4.0/), which permits unrestricted use, distribution, and reproduction in any medium, provided you give appropriate credit to the original author(s) and the source, provide a link to the Creative Commons license, and indicate if changes were made. The Creative Commons Public Domain Dedication waiver (http://creativecommons.org/publicdomain/zero/1.0/) applies to the data made available in this article, unless otherwise stated. 


\section{Background}

Since 2002, the Israel Quality Indicators in Community Healthcare $(\mathrm{QICH})$ program has monitored ambulatory care for the Israeli population using electronic health care records. Indicators were created with the consensus of health plans and the Israeli medical association. Diabetes was one of the initial conditions and was expanded in 2006 to include intermediate outcome data [1] similar to the National Committee for Quality Assurance (NCQA) measures approved for implementation in 2007 [2]. The QICH denominator differed by including only those patients receiving oral agents or insulin.

Calderon-Margalit et al. [3] report improved trends in adherence to process outcomes and intermediate outcomes from 2002 to 2010. Since all patients received medications, the improvement is not likely to be attributable to increased prevalence of new-onset diabetes. However, without stratification trends in the $<65$ and 65-74-year age groups could not be assessed.

Additionally, there was a positive association of the composite quality indicator score with rates of end-stage complications and mortality from 2006 to 2012, accounting for a lag period. These findings are similar to United States [US] trends [4]. However, unmeasured factors, such as decreased smoking rates or improved care delivery, could be more important than intermediate outcome measures, especially given the short lag time.

QICH continued to utilize the NCQA measures [ $<130 / 80 \mathrm{~mm} / \mathrm{Hg},<7 \% \mathrm{~A} 1 \mathrm{c}]$ through 2010 for all patients 18-74 years, although HEDIS revised them in 2008 after early termination of the ACCORD Study. However, after 2012, QICH significantly revised the measures (Ronit Calderon, personal communication). The changes included identification of patients by laboratory value; changing the target values of A1c to $<8 \%$ for older patients and those with duration of diabetes greater than 10 years; assessment of patients with nephropathy receiving ACEI/ARB therapy; and changing the frequency of eye examinations from annually to every other year.

\section{Commentary}

What lessons from the QICH experience may be generalized to OCED nations, including the United States (US)?

First, the QICH program provides no financial payments for physicians or plans. Presumably professionalism is the motivation for improved trends, although we cannot exclude peer pressure. This approach warrants careful consideration by US Healthcare leaders.

Second, QICH made evidence-based changes in measures. For example, setting higher A1c targets not only for older patients, but also for those with longer duration diabetes of diabetes, is appropriate with the risk/benefit in these individuals, as first proposed in the 2003 Department of Veterans Affairs/Department of Defense Diabetes
(VA/DoD) Guidelines [5]. The use of A1c for inclusion into the measurement cohort can identify undiagnosed diabetes; in the US, about $24 \%$ of patients were unaware of or did not report having diabetes in 2015 [6].

However, neither QICH nor US organizations have developed glycemic measures consistent with the most recent guidelines from the American Geriatrics Society [7], the American Diabetes Association [8], VA/DoD [9], and the American College of Physicians [10]. These guidelines all recommend individualized A1c target values of 8.0 to 8.5\% (and even 9.0\%) for older adults with diabetes based upon the presence of multiple serious complex conditions or poor health/frailty. About half of the US population 65-69 years of age fall into these categories [11]. The American College of Physicians has recently recommended that there should be no performance measurement targets in patients for whom avoidance of symptoms may be an appropriate goal [10].

Additionally, the US Department of Health and Human Services published a report that recommended that the < $8 \%$ A1c measure for older adults be revisited as part of a national strategy to reduce serious hypoglycemia [12]. The report specifically recommended excluding individuals with co-morbid conditions, stratifying by medications, and including a $<7 \%$ A1c balancing measure [13] to identify overtreatment. The NQF endorsed "Optimal Composite Measure" includes < 8\% A1c limits exclusion criteria only for death, permanent nursing home, or hospice care.

In contrast, we have proposed [14] that glycemic measures for older patients on hypoglycemic agents with comorbid conditions should have accountability thresholds only for extremes of control (<7\% A1c and $>9 \%$ A1c) and define an acceptable middle range $(7.5 \%-8.5 \% \mathrm{~A} 1 \mathrm{c})$ for quality improvement consistent with evidence and laboratory science [15].

Finally, neither QICH nor the US have been proactive in developing timely surveillance systems to evaluate harms that can result from poorly specified population health measures-the Black Swan effect [16]. The most concerning example is that marketing of $<7 \%$, which began in 2002, may have contributed to an increase in serious hypoglycemia in the older US population [17]. High rates of $<7 \%$ A1c in sicker, older adults on hypoglycemic agents persist in the UA Federal [18] and private [19] sectors.

The challenge for $\mathrm{QICH}$ is to translate lessons from Israel and the US into furthering the development of guideline concordant measures that can assess population health while simultaneously respecting the principle of patient autonomy (respect for persons). We propose the following:

(1) Israel could consider organizing an international meeting to address diabetes measures, thus taking 
the lead in reforming diabetes performance measurement.

(2) Performance measurement organizations should immediately eliminate the use of "adjectives" to define "measures". In the US the term "optimal" is used, whereas the QICH measure is deemed "appropriate"-perhaps "recommended" would be more neutral. Adjectives intrude upon the concept of beneficence defined by the individual assessment of benefit and risks.

(3) Develop/adapt measures to assess the development of an individualized target A1c goal in lieu of a specific target for older adults including, at least 1) age, 2) comorbidities, and 3) risk for hypoglycemia. This was proposed by the US Centers for Medicare and Medicaid Services in 2016, but not adopted [20]. Substantial evidence supports shared decision making as enhancing patient satisfaction and physician trust are enhanced, even if intermediate outcomes are not improved [9]. The National Quality Forum has recently recommended development of measures for shared decision making [21].

\section{Conclusion}

Balancing benefits and harms of treatment for individuals while monitoring population health will require a major shift in our approach to diabetes performance measurement. It will be necessary, for some measures, to involve patients and clinicians in setting personalized goals rather than being dictated by "meeting a measure". Treatment decisions require knowledge-guided by professionalism and patient consent, guided by ethics [22]. "The physician should not treat the disease but the patient who is suffering from it (Rambam)."

\section{Authors' contributions}

LP and DA contributed equally to the commentary. Both authors read and approved the final manuscript.

\section{Authors' information}

Drs. Aron and Pogach have published extensively on the topic of diabetes guidelines, medication safety, and diabetes performance measures. The opinions expressed are solely those of the authors, and do not represent any institution or agency.

\section{Ethics approval and consent to participate}

Not applicable.

\section{Competing interests}

The authors declare that they have no competing interest.

\section{Publisher's Note}

Springer Nature remains neutral with regard to jurisdictional claims in published maps and institutional affiliations.
Received: 24 March 2018 Accepted: 19 April 2018

Published online: 03 May 2018

\section{References}

1. Jaffe DH, Shmueli A, Ben-Yehuda A, Paltiel O, Calderon R, Cohen AD, Matz E, Rosenblum JK, Wilf-Miron R, Manor O. Community healthcare in Israel: quality indicators 2007-2009. Isr J Health Policy Res. 2012;1(1):3. https://doi.org/10.1186/2045-4015-1-3.

2. Pogach L, Aron D. Sudden acceleration of diabetes quality measures: time to pull the Andon cord? JAMA. 2009;305(7):709-10.

3. Calderon-Margalit R, Cohen-Dadi M, Opas D, Jaffe DH, Levine J, Ben-Yehuda A, Paltiel O, Manor O. Trends in the performance of quality indicators for diabetes care in the community and in diabetes-related health status: an Israeli ecological study.Isr J Health Policy Res. 2018 7:10https://ijhpr. biomedcentral.com/articles/10.1186/s13584-018-0206-3

4. Gregg EW, Li Y, Wang J, Burrows NR, Ali MK, Rolka D, Williams DE, Geiss L. Changes in diabetes-related complications in the United States, 1990-2010. N Engl J Med. 2014:370(16):1514-23.

5. Pogach LM, Brietzke SA, Weinstock R, Downs JR, Cowan C, Pugh J, Walder DJ, Sawin CT. The VA/DoD diabetes guideline development group. Development of evidence-based guidelines for diabetes mellitus: the veterans health Administration-Department of Defense Guidelines Initiative. Diabetes Care. 2004;27(Supplement 2):B82-89.6.

6. National Diabetes Statistics Report, 2017 Estimates of Diabetes and Its Burden in the United States. The. Centers for Disease Control and Prevention. https://www.cdc.gov/diabetes/pdfs/data/statistics/nationaldiabetes-statistics-report.pdf. Accessed 25 Apr 2018.

7. American Geriatrics Society Expert Panel on the Care of Older Adults with Diabetes Mellitus. Guidelines abstracted from the American Geriatrics Society guidelines for improving the Care of Older Adults with diabetes mellitus: 2013 update. J Am Geriatr Soc. 2013;61(11):2020-6.

8. Older Adults: Standards of Medical Care in Diabetes - 2018. American Diabetes Association http://care.diabetesjournals.org/content/41/Supplement_1/S119. Accessed 25 Apr 2018.

9. Conlin P, Colburn J, Aron D, Pries R, Tschanz M, Pogach L. Synopsis of the 2017 U.S. department of veterans affairs/U.S. department of defense clinical practice guideline: management of type 2 diabetes mellitus. Ann Intern Med. 2017;167(9):655-63.

10. Annals of Internal Medicine. 2018. Hemoglobin A 1 Targets for Glycemic Control With Pharmacologic Therapy for Nonpregnant Adults With Type 2 Diabetes Mellitus: A Guidance Statement Update From the American College of Physicians. http://annals.org/aim/fullarticle/2674121/hemoglobin1c-targets-glycemic-control-pharmacologic-therapy-nonpregnant-adultstype. Annals Internal Medicine 2018. Accessed 25 Apr 2018.

11. Lipska KJ, Ross JS, Miao Y, et al. Potential overtreatment of diabetes mellitus in older adults with tight glycemic control. JAMA Intern Med. 2015;175(3):356-62.

12. National Action Plan for Adverse Drug Event Prevention (Diabetes Agents), 2014, p. 117. National Action Plan for Adverse Drug Event Prevention https:// health.gov/hcq/pdfs/ade-action-plan-508c.pdf. Accessed 25 Apr 2018.

13. Pogach $L$, Aron DC. The other side of quality improvement in diabetes for seniors: a proposal for an overtreatment glycemic measure. Arch Int Med 2012;172(19):1510-1512. [PubMed: 22965316].

14. Pogach L, Tseng CL, Soroka O, Maney M, Aron D. A proposal for an out-ofrange glycemic population health safety measure for older adults with diabetes. Diabetes Care. 2017:4:518-25. Epub 2016 Nov 15

15. Diabetes \& Prediabetes Tests. National Diabetes,Digestive and Kidney Diseases. National Diabetes Information Clearinghouse. https://niddk.nih. gov/health-information/diagnostic-tests/diabetes-prediabetes. Accessed 25 Apr 2018.

16. Aron DC. No "black swan": unintended but not unanticipated consequences of diabetes performance measurement. Jt Comm J Qual Patient Saf. 2013; 39(3):106-8

17. Lipska KJ, Ross JS, Wang Y, et al. National trends in US hospital admissions for hyperglycemia and hypoglycemia among Medicare beneficiaries, 1999 to 2011. JAMA Intern Med. 2014;174(7):1116-24.

18. Tseng CL, Soroka O, Maney M, Aron DC, Pogach LM. Assessing potential glycemic overtreatment in persons at hypoglycemic risk. JAMA Intern Med. 2014;174(2):259-68.

19. Lipska KJ, Yao X, Herrin J, McCoy RG, Ross JS, Steinman MA, Inzucchi SE, Gill TM, Krumholz HM, Shah ND. Trends in drug utilization, glycemic control, 
and rates of severe hypoglycemia, 2006-2013. Diabetes Care. 2017 Apr;40(4): 468-75. https://doi.org/10.2337/dc16-0985.

20. Medicare Program; Merit-Based Incentive Payment System (MIPS) and Alternative Payment Model (APM) Incentive Under the Physician Fee Schedule, and Criteria for Physician-Focused Payment Models https:// www.gpo.gov/fdsys/pkg/FR-2016-05-09/pdf/2016-10032.pdf. Federal Register Nol. 81, No. 89/Monday, May 9, 2016/Proposed Rules. Accessed 25 Apr 2018.

21. NQF Issues Vital Guidance to Improve Shared Decision Making Between Patients and Healthcare Providers. http://www.qualityforum.org/Guidance_ to_Improve_Shared_Decision_Making.aspx. Accessed 25 Apr 2018.

22. Agarwal AK, Murinson BB. New dimensions in patient-physician interaction: values, autonomy, and medical information in the patient-centered clinical encounter. Rambam Maimonides Med J. 2012;3(3):e0017. Published online 2012 Jul 31

Ready to submit your research? Choose BMC and benefit from:

- fast, convenient online submission

- thorough peer review by experienced researchers in your field

- rapid publication on acceptance

- support for research data, including large and complex data types

- gold Open Access which fosters wider collaboration and increased citations

- maximum visibility for your research: over $100 \mathrm{M}$ website views per year 